Original article

\title{
Changes to the structure of the hydrographic network within the Silesia-Cracow area
} of zinc and lead exploitation

\author{
Alicja Pradela ${ }^{1}$, Andrzej Zygmuniak ${ }^{2}$, \\ 1Department of Physical Geography, Faculty of Earth Sciences, Będzińska Str. 60, 41-200 Sosnowiec, Poland \\ 2Faculty of Mining and Geology, Silesian University of Technology, Akademicka Str. 2, Gliwice, Poland \\ E-mail address (corresponding author): alicjapradela@wp.pl
}

\section{ABSTRACT}

The traditions related to mining activities in the Silesia-Cracow area go back to the $11^{\text {th }}$ century when lead, silver, and iron ores were exploited from open pit mines. For centuries, the growth in ore exploitation was an incentive for the development of other industries (hard coal mining, steelmaking). This, in consequence, resulted in progressive urbanization. The areas analyzed are of highly transformed character, mainly because of mining activities. These changes are especially seen in relation to the aquatic environment since this component is exposed to heavy modifications due to the mining processes. Hence the study was carried out in order to determine the quantitative changes in the surface hydrographic network. It was found, that of the 62 main watercourses (existing during the whole analyzed period) 25 changed only slightly in terms of their length, 20 shortened by a few hundred meters and 17 lengthened. In the case of the aggregated length of the tributaries, the value increased for the 41 main watercourses, for 10 of them it was constant and was reduced slightly for a further 11 . The areas where the length of the watercourses increased and the drainage density grew were found to be as well those where the total area of wetlands decreased. The element of the hydrographic network which was affected by the most changes was the water bodies. During the analyzed period of over 200 years, their number increased from 154 to 1413.

KEY WORDS: zinc and lead deposit, mining, Silesia-Cracow deposit area, hydrographic network, water body, wetland ARTICLE HISTORY: received 12 May 2017; received in revised form 19 June 2017; accepted 20 June 2017

\section{Introduction}

Parts of the Silesia and Cracow region where zinc and lead ores were exploited, is one of the most urbanized and industrialized areas of Poland, and have been under heavy anthropogenic stress over the last centuries. As there are not only the above-mentioned minerals but also many others (hard coal, non-ferrous metal ores, rock material) the mining industry is well developed in the region. At the time when heavy industry was established the cities of the area experienced a process of intense urbanization. Any action performed due to the anthropogenic stress of such character leads to a number of transformations which have an effect on the geographical environment as a whole (JANKOWSKI, 1991; CZAJA, 1999). The most distinctive changes are those connected with the structure of the surface hydrographic network. Thus a question about the real influence on that network caused by a specific anthropogenic stress emerges as well as what are the characteristics that describe the changes that have happened. The aim of this study is to determine what are the direct and indirect consequences of these components that have arisen from the human activities in this area - in terms of the zinc and lead exploitation (and silver, to a lesser extent).

Because of the lack of source materials, the transformations which affected the hydrographic network were determined strictly for the period from the beginning of the $19^{\text {th }}$ century until now. This paper thoroughly describes, in volume terms, the transformation of the specific hydrographic parts since the $19^{\text {th }}$ century, which are as follows: watercourses, water basins, and wetlands. 
Furthermore, the study shows which ones of them were affected, directly or indirectly, by the exploitation of lead and zinc ores, and which ones changed due to other co-existing anthropogenic stress factors.

\section{The area of study}

The boundaries of the area being analyzed, named as the Silesia-Cracow deposit region, were determined on the basis of the coverage of mining exploitation. This was shown on the mining field maps from the mid-20 $0^{\text {th }}$ century and provided for the ore mines. In the next step, the zone was modified, so the watercourses would be limited to the cross sections. These were determined by combining all of the source map material and defining the common infrastructure (e.g. bridges or crossroads etc.). However, there were significant discrepancies between river courses, so it was not possible to strictly define the boundary of the research area. It was assumed that such a discrepancy will result in an individual approach when analyzing the specific hydrographic net element. The whole of the area analyzed covers almost $1185 \mathrm{~km}^{2}$.

The Silesia-Cracow deposit area is located within two physico-geographical provinces. The north and the north-western section is part of the Northern European Lowlands, the Opole Plain to be precise, which in turn is incorporated into the Silesian Lowlands macroregion, Central Poland Lowland subprovince. The remaining section of the research area entirely incorporates into units which form the Poland Uplands province, the SilesiaCracow Upland subprovince. The vast majority of this section is located within the mesoregions: Katowice Upland, Tarnowskie Góry Hummock, and Jaworzno Hummock. These are parts of the Silesian Upland macroregion. However, the south and south-eastern part are within the following units of the Cracow-Częstochowa Upland macroregion: Częstochowa Upland, Olkusz Upland, Krzeszowice Trench, and Tenczynek Hummock (KondRACKI, 2000, Fig. 1).

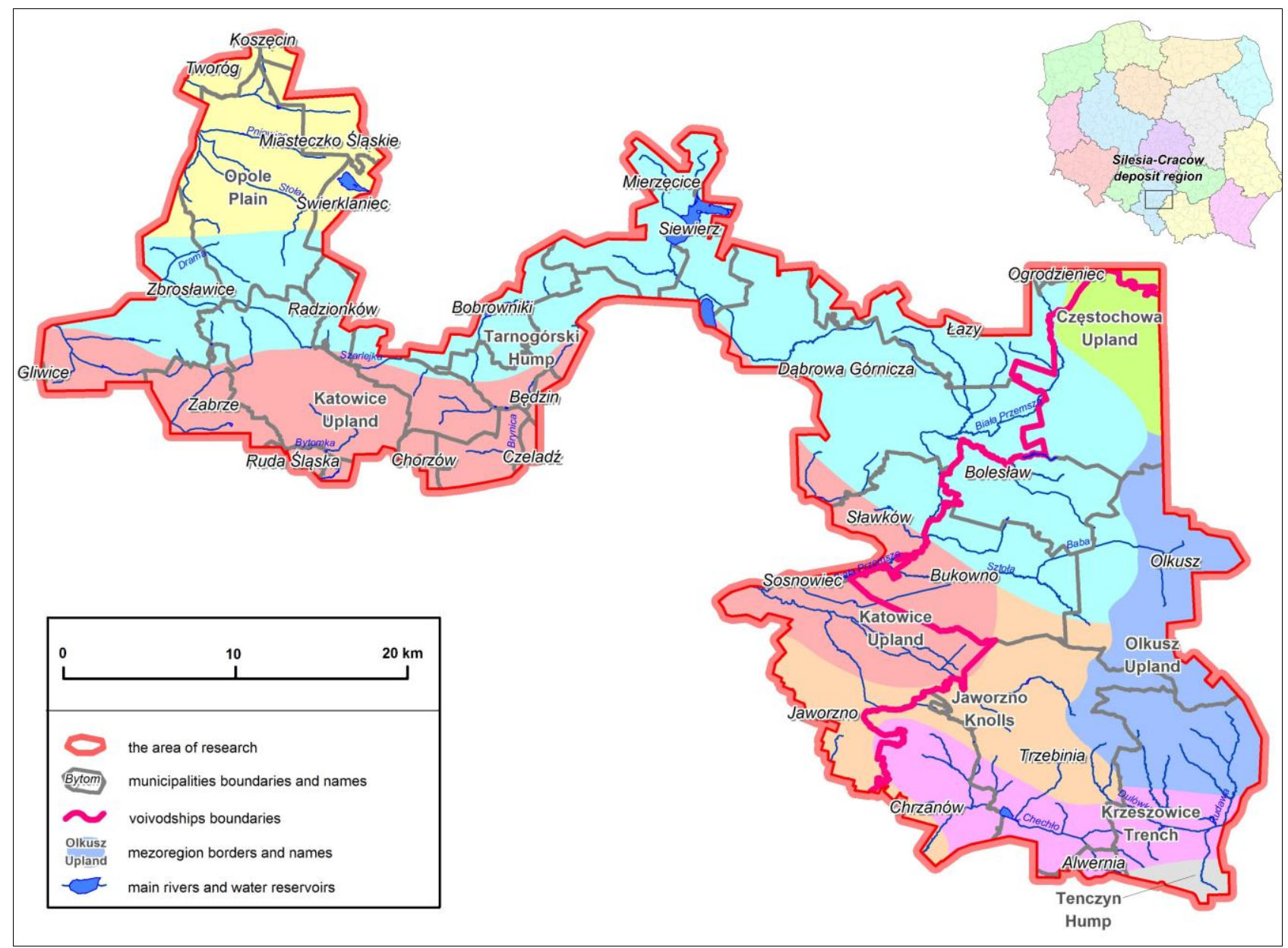

Fig. 1. The research area (http://dm.pgi.gov.pl and http://mapy.geoportal.gov.pl) 


\section{The source material and methods of study}

The core source material consists of archive and contemporary cartographic material. Galician topographic maps at a scale of $1: 28,000$, dating back to the beginning of the $19^{\text {th }}$ century, as well as Prussian ones from the $1820 \mathrm{~s}$, at a scale of $1: 25,000$ were used for the presentation of the surface layout of the hydrographic network. Undoubtedly, these maps are least accurate and it should be noted that adjustment between a map and a specific actual object ranges from $15 \mathrm{~m}$, in the case of the Prussian maps, to ca. $50 \mathrm{~m}$ when the Galician ones are considered. The cartographic material for the end of the $19^{\text {th }}$ century consists of the Russian maps: Polish hard coal mines maps by LEMPICKI \& HATTOWSKI from 1891 at a scale of $1: 10,000$, Galician maps from the 1860s at a scale of 1:28,000, and Prussian maps called "Messtischblatt" (niem. Meßtischblätter) from the 1880 s at a scale of $1: 25,000$. These maps are of high terrain characteristics representation accuracy and the adjustment between a map and the modern topographic layout ranges from ca. $10 \mathrm{~m}$ for the Prussian maps to ca. $30 \mathrm{~m}$ for the Russian ones. For the beginning of the $20^{\text {th }}$ century, the area of research has been split up. The western part was analyzed with the use of German maps, originating from the 1940s, at a scale of 1:25,000, while the eastern and south-eastern ones were studied based on the Military Institute of Geography (pol. Wojskowy Instytut Geograficzny) originating from the 1930s and at a scale of 1:25,000. These maps are characterized by the high level of details and adjust to terrain objects with an accuracy of $\pm 12 \mathrm{~m}$. Data processed in relation to the period at the end of the $20^{\text {th }}$ century were based upon the topographic maps at a scale of $1: 10,000$. These have been released starting from 1993 and their timeliness are determined to be ranging from 1991 to 1994 . As it comes to the $21^{\text {st }}$ century, the Generic Topographic Object Database (pol. Baza Danych Ogólnotopograficznych, TBD) was applied to the study. It is provided in form of a WMS service. Maps acquired in such a way are equal to a regular one at a scale of $1: 10,000$ in terms of accuracy as well as presenting the actual situation for the years 2012-2013.

The general affine transformation was used as a method for adjusting maps to the actual situation (thus for transforming them into the Coordinate System 1992). During the process of the raster calibration, at least 15 (more, if possible) adapting points were chosen on each of them. The translation of rasters was done with use of MapInfoPro 15.2
The tracing process carried out for the content of the maps related to the hydrographic network was the basis for further studies. All performed analyzes were also conducted with the MapInfoPro 15.2 software. It was performed for the watercourses, water bodies, and wetlands. For each group, a database was established which, in consequence, made it possible to draw up a statement concerning the network elements in terms of space and time (change of the length in relation to the watercourses and the area for the water basins, as well as the variability of their existence). Moreover, different cartographic products were developed, so the changes concerning the analyzed network that took place over time will be shown in a holistic way. One of the abovementioned products was a cartogram which shows the spatial features of the network for the analyzed time periods (i.e. drainage density, the percentage of water bodies and wetlands). Having them prepared allowed the next step which was to cross-reference them, so, as a result, the maps representing changes of a specific factor have been produced. For this purpose, an analysis was performed on the cartograms to determine which of the single meshes overlap each other. This process was applied for each specific time period. In effect, the single meshes were indicated if the parameter: 1) had an increasing trend; 2) had a decreasing trend; 3) seemed not to change; 4) occurred irregularly; 5) did not occur at all.

In order to perform a full analysis of the anthropogenic factors which influence the hydrographic network within the research area, databases consisting of the data on the urban infrastructure, the green areas (green areas covered by low vegetation, forest and rural areas), and the areas of mining activities (mining areas for the hard coal mines, lead and zinc ores, iron workings, quarries and sandpits) were established. The area affected by mining was determined based on documents shared by the historic mine in Tarnowskie Góry, documents from the ZGH Bolesław archive, the data provided by RóżKOWSKI \& WILK (1980), the analyzed topographic maps and the data provided within the dm.pgi.gov.pl portal. Databases established in that way allowed the isolation of the areas in which the hydrographic network changed depending on the sealing of the soil, the level of development of the land drainage system, and the drainage caused by the mining activities or those affected by terrain changes. 


\section{Results}

In the area of the Silesian-Cracow deposit during the analyzed time there were 69 watercourses, which can be named as main ones (they had their own names). In 62 cases the watercourses were present during all of the analyzed periods, whereas 7 of them were found to be affected by a discontinuity of existence. This means that they did not exist during at least one of the periods. The layout of 45 main watercourses are located entirely within the research area. In 25 cases changes to the watercourse length were negligible because they did not exceed a few hundred meters. Part of this value should be taken into consideration as an inaccuracy which is a result of the transformation process performed on the map rasters as well as of the tracing faults. Other changes were caused by partial or full river adjustment. A significant drop in the watercourse length, exceeding a few hundred meters or even a few kilometers, was observed in 20 cases, whereas in 17 cases the overall watercourse length increased by a similar value (Table 1 ).

Table 1. The statement of watercourse lengths (private study based on databases)

\begin{tabular}{|c|c|c|}
\hline Names of watercourses & Changes to the watercourses length & Changes to the tributaries length \\
\hline Baba & $\Delta$ & $\cdot$ \\
\hline Balinianka & $\Delta$ & $\nabla$ \\
\hline Biała & $\nabla$ & $\Delta$ \\
\hline Biała Przemsza & $\bullet$ & $\Delta$ \\
\hline Bobrek & $\nabla$ & $\Delta$ \\
\hline Brynica & $\nabla$ & $\nabla$ \\
\hline Bytomka & $\bullet$ & $\nabla$ \\
\hline Centuria & $\Delta$ & $\Delta$ \\
\hline Chechło & $\bullet$ & $\Delta$ \\
\hline Dąbrówka & - & $\nabla$ \\
\hline Debieszówka & $\cdot$ & $\nabla$ \\
\hline Dopływ spod gaj. za Białką & $\bullet$ & $\Delta$ \\
\hline Dopływ spod Górników & $\bullet$ & $\Delta$ \\
\hline Dopływ spod Karniowic & $\bullet$ & $\bullet$ \\
\hline Dopływ spod Kowalskiej Góry & $\bullet$ & 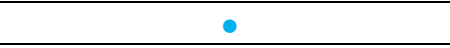 \\
\hline Dopływ spod Mikołeski & $\bullet$ & $\Delta$ \\
\hline Dopływ spod Piasków & $\nabla$ & $\Delta$ \\
\hline Dopływ spod Rybnej & $\Delta$ & $\Delta$ \\
\hline Dopływ z Laryszowa & $\Delta$ & $\Delta$ \\
\hline Dopływ z Przezchlebia & $\bullet$ & $\Delta$ \\
\hline Dopływ z Ptakowic & $\Delta$ & $\Delta$ \\
\hline Dopływ z Woli Filipowskiej & 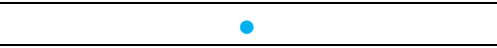 & $\Delta$ \\
\hline Drama & $\bullet$ & $\Delta$ \\
\hline Dulówka & $\nabla$ & $\Delta$ \\
\hline Filipówka & $\Delta$ & $\bullet$ \\
\hline Graniczna Woda & $\nabla$ & $\Delta$ \\
\hline Jedlinka (Grzybowicki Potok) & $\Delta$ & $\Delta$ \\
\hline Kozi Bród & $\nabla$ & $\nabla$ \\
\hline Luszówka & $\nabla$ & $\nabla$ \\
\hline Łużnik & $\nabla$ & $\Delta$ \\
\hline Miękinia & $\nabla$ & $\nabla$ \\
\hline Mikulczycki Potok & $\bullet$ & $\bullet$ \\
\hline Myślachówka & $\nabla$ & $\Delta$ \\
\hline Olszówka & 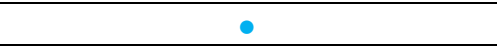 & $\Delta$ \\
\hline Pniowiec & $\nabla$ & $\Delta$ \\
\hline Potok Błędowski & $\Delta$ & $\Delta$ \\
\hline Potok Jeziorowicki & $\Delta$ & $\Delta$ \\
\hline Przemsza & $\nabla$ & $\Delta$ \\
\hline Pstrążnik & $\nabla$ & $\nabla$ \\
\hline Rakówka & $\bullet$ & $\Delta$ \\
\hline Ropa & 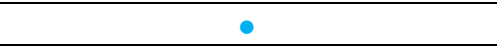 & $\nabla$ \\
\hline Rów Michałkowicki & $\nabla$ & $\bullet$ \\
\hline Rów Radzionkowski & $\nabla$ & $\bullet$ \\
\hline
\end{tabular}




\begin{tabular}{|l|c|c|}
\hline Rów z Dąbrówki Wielkiej & $\Delta$ & $\boldsymbol{\nabla}$ \\
\hline Rudawa & $\bullet$ & $\boldsymbol{\nabla}$ \\
\hline Starotarnowicki Potok & $\boldsymbol{\nabla}$ & $\boldsymbol{\Delta}$ \\
\hline Stoła & $\boldsymbol{\Delta}$ & $\boldsymbol{\Delta}$ \\
\hline Strumień Błędowski & $\bullet$ & $\boldsymbol{\Delta}$ \\
\hline Szarlejka & $\bullet$ & $\boldsymbol{\Delta}$ \\
\hline Sztolnia & $\boldsymbol{\Delta}$ & $\boldsymbol{\Delta}$ \\
\hline Sztolnia Ponikowska & $\bullet$ & $\mathbf{\Delta}$ \\
\hline Sztoła & $\boldsymbol{\Delta}$ & $\boldsymbol{\Delta}$ \\
\hline Trzebyczka & $\bullet$ & $\bullet$ \\
\hline Wieszówka & $\boldsymbol{\nabla}$ & $\mathbf{\Delta}$ \\
\hline Wodna & $\bullet$ & \\
\hline Żabnik & $\boldsymbol{\nabla}$ & \\
\hline Żernicki Potok & & \\
\hline
\end{tabular}

Symbols: $\Delta$ - the parameter was of an increasing trend; $\bullet$ - the parameter seemed not to change ; $\boldsymbol{\nabla}$ - the parameter was of a decreasing trend

The situation is different when concerned with the aggregate length of all main watercourse tributaries (the watercourses not distinguished are a network of tributaries, including drainage ditches). During the analyzed period this parameter increased for 41 watercourses, in some cases it exceeded the value of one hundred kilometers. For the 10 main watercourses, the network of tributaries did not change significantly, and for the other 11 their aggregated length has been shortening (Table 1). The anthropogenic impact map and the cartograms prepared for this study represent the phenomenon which showed the most substantial increase in drainage density which was observed within the drained green areas (forests, farmlands, wastelands) which were not subject to the conversion caused by mining activities. On the other hand, areas, where either dense or dispersed building complexes or industry have been developed, were those of highest drainage density decrease (Fig. 2). It should be noted that in the areas which are, and were, directly affected by the zinc and lead ore mining, the drainage density decreased to a very limited extent. Such a situation took place despite the fact that the character of mining activities leads inevitably to atrophy of the watercourses, source displacements, and flow decrease.

At the beginning of the $19^{\text {th }}$ century, wetlands existed within most river valleys and, in many cases, they themselves were a source area for watercourses. This took place primarily in the Cracow part of the research area. Next analyzed periods showed that the percentage of wetlands decreased from over $2.6 \%\left(30 \mathrm{~km}^{2}\right)$ in the beginning of the $19^{\text {th }}$ century to ca. $0.3 \%\left(4 \mathrm{~km}^{2}\right)$ at the turn of the $20^{\text {th }}$ and $21^{\text {st }}$ centuries. The coverage was highly irregular. Within the vast majority of the research area sections, the presence of wetlands did not exceed the number of two. Only in the forest areas where the drainage density has grown, the abovementioned parameter significantly decreased (Fig. 3).

Undoubtedly, the most affected and changed elements of the hydrographic network were the water bodies. Their number in the beginning of the $19^{\text {th }}$ century was 154 , which rose over 50 years and was 696 at the turn of the $19^{\text {th }}$ and 20th centuries, amounted to ca. 1500 (1483 at the end of the $20^{\text {th }}$ century and 1413 at the beginning of the $21^{\text {st }}$ century). The majority of water bodies were very small (the area not exceeding $1 \mathrm{ha}$ ) being of ca. $90 \%$ of all analyzed water bodies. In this group, the vast majority consisted of water bodies ranging in total area from 0.1 to 0.5 ha (56\% at the beginning of the $19^{\text {th }}$ century and $90 \%$ at the end). However, the percentage of water bodies of such an area had been gradually decreasing from the beginning of the $20^{\text {th }}$ century and reached $76 \%$ one hundred years later. At the same time, an increase in the number of water bodies whose area was between 0.5 and 1.0 ha was observed. At the turn of the $20^{\text {th }}$ and $21^{\text {st }}$ centuries the number of very large water bodies, those exceeding 10 ha, was definitely higher. At the end of the $20^{\text {th }}$ century there were 11 of them, and 10 at the beginning of the $21^{\text {st }}$ century. In the beginning of the $19^{\text {th }}$ century water bodies of this size did not exist, however, there was one of each kind at the end of it and in the beginning of the 20th century. During the analyzed time, closed water bodies dominated over open ones. From the end of the $19^{\text {th }}$ century, and for over 100 years, they amounted to almost $90 \%$ of all water bodies in the area. Only at the beginning of the $1^{\text {th }}$ century, were there significantly less closed water bodies - ca. 30\% (Fig. 4-8). 


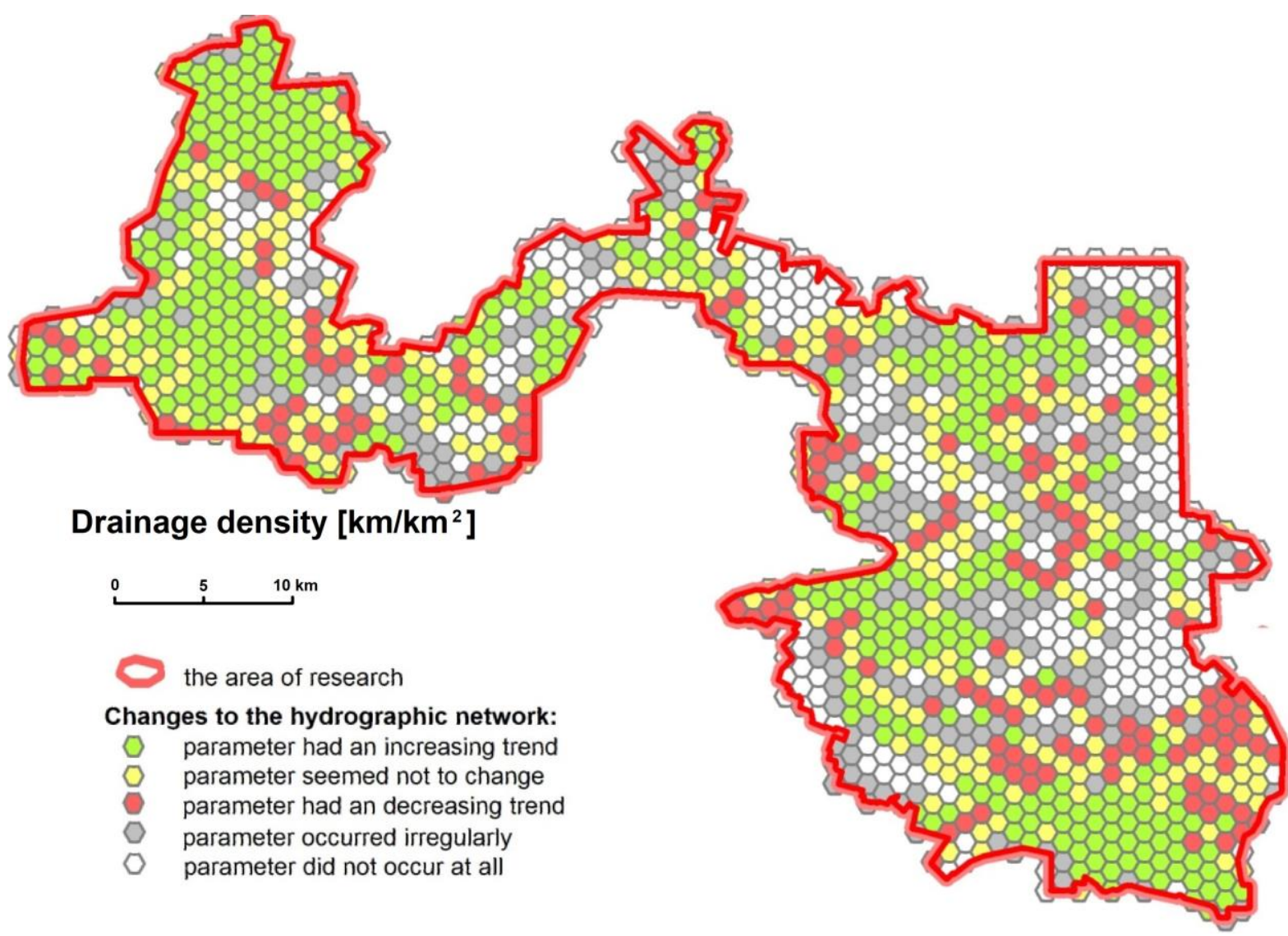

Fig. 2. Map of changes to the drainage density (A - the beginning of the $19^{\text {th }}$ century, B - the end of the $19^{\text {th }}$ century, C - the beginning of the $20^{\text {th }}$ century, $\mathrm{D}$ the end of the $20^{\text {th }}$ century, $\mathrm{E} \neg$ the beginning of the $21^{\text {st }}$ century; own study based on the created databases)

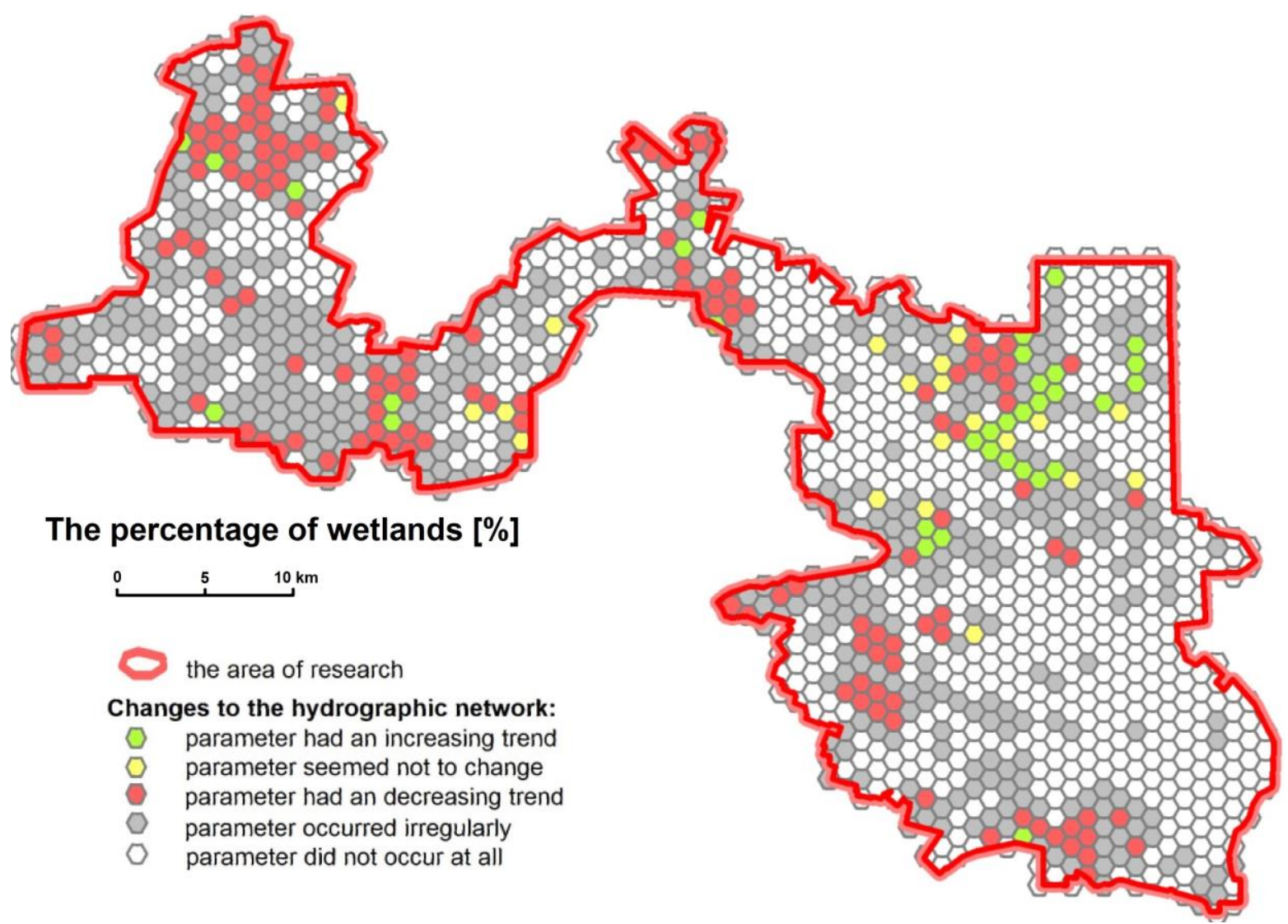

Fig. 3. Map of changes to the percentage of wetlands (A - the beginning of the $19^{\text {th }}$ century, $\mathrm{B}$ - the end of the $19^{\text {th }}$ century, C - the beginning of the $20^{\text {th }}$ century, $\mathrm{D}$ the end of the $20^{\text {th }}$ century, $\mathrm{E} \neg$ the beginning of the $21^{\text {st }}$ century; own study based on the created databases) 

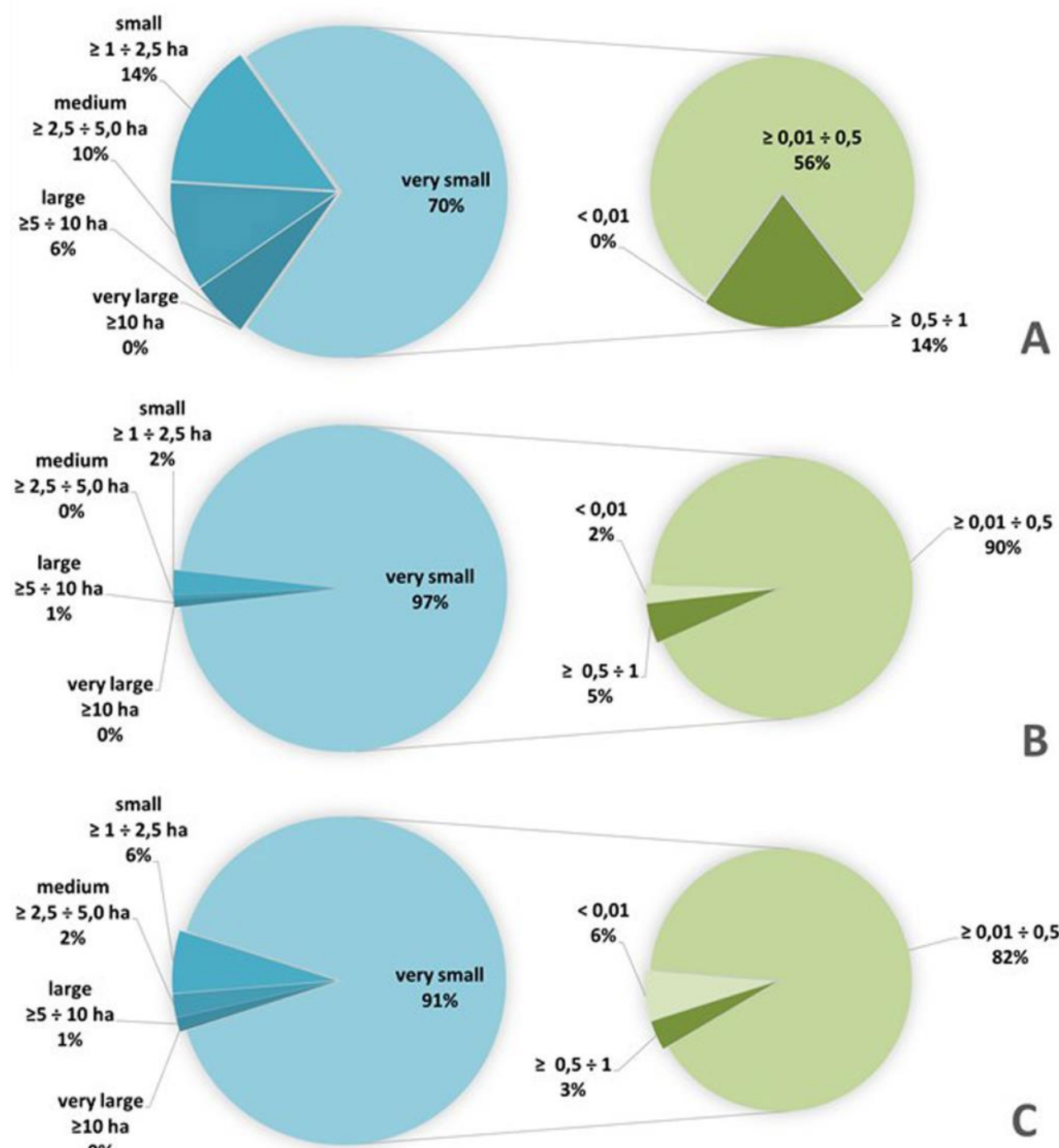

$0 \%$

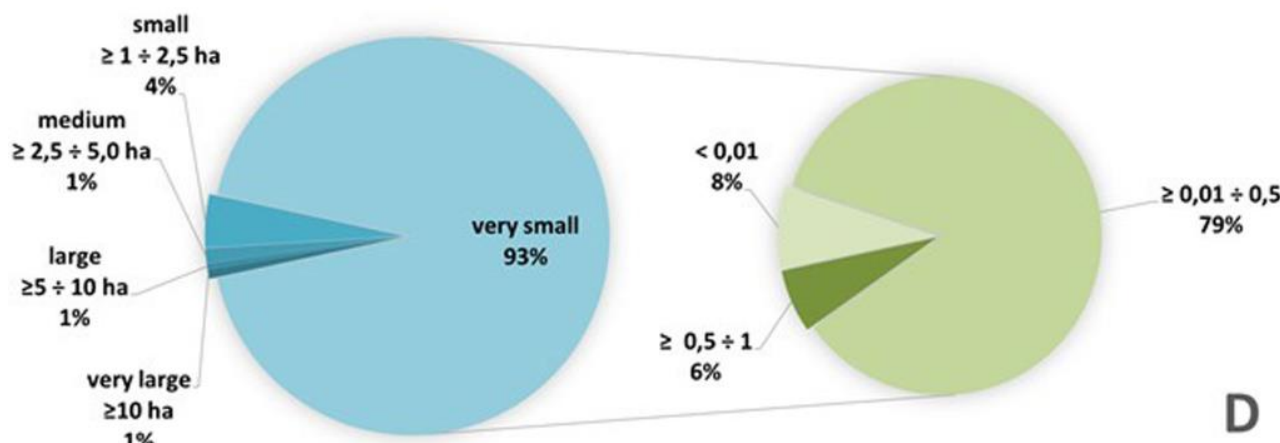

$1 \%$

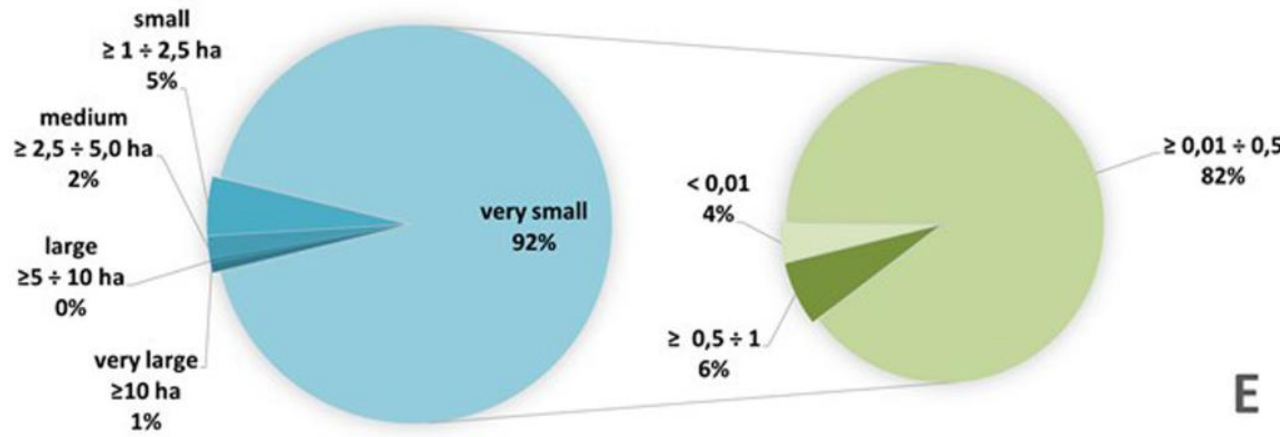

Fig. 4. Number of water bodies by their area (A - the beginning of the $19^{\text {th }}$ century, B - the end of the $19^{\text {th }}$ century, C - the beginning of the $20^{\text {th }}$ century, $\mathrm{D}$ the end of the $20^{\text {th }}$ century, $\mathrm{E} \neg$ the beginning of the $21^{\text {st }}$ century; own study based on databases) 
A

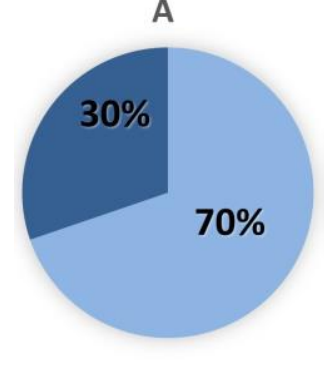

B

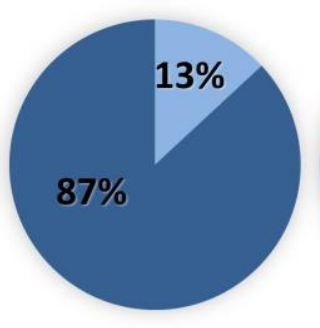

open

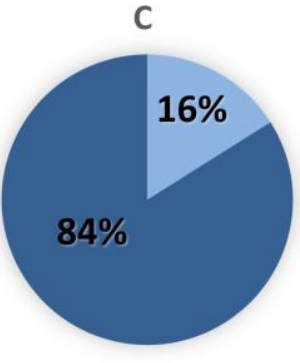

口

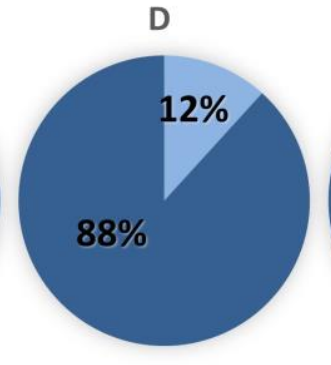

closed

Fig. 5. Number of water bodies by their hydrological type (A - the beginning of the $19^{\text {th }}$ century, B - the end of the $19^{\text {th }}$ century, C - the beginning of the $20^{\text {th }}$ century, $\mathrm{D}$ the end of the $20^{\text {th }}$ century, $\mathrm{E} \neg$ the beginning of the $21^{\text {st }}$ century; own study based on databases)

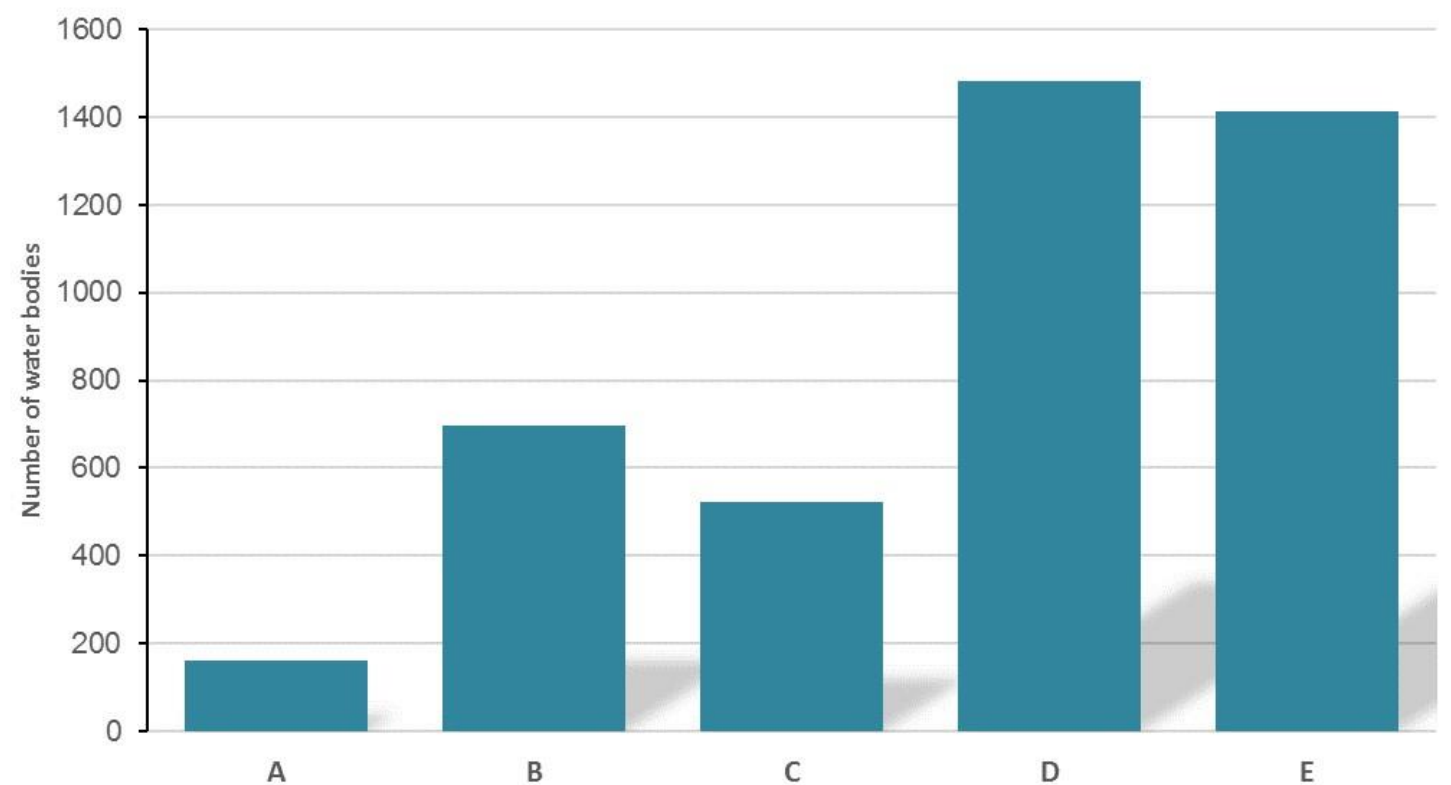

Fig. 6. Number of water bodies provided for specific time periods: A - the beginning of the $19^{\text {th }}$ century, B - the end of the $19^{\text {th }}$ century, $\mathrm{C}$ - the beginning of the $20^{\text {th }}$ century, D- the end of the $20^{\text {th }}$ century, E - the beginning of the $21^{\text {st }}$ century (own study based on databases)

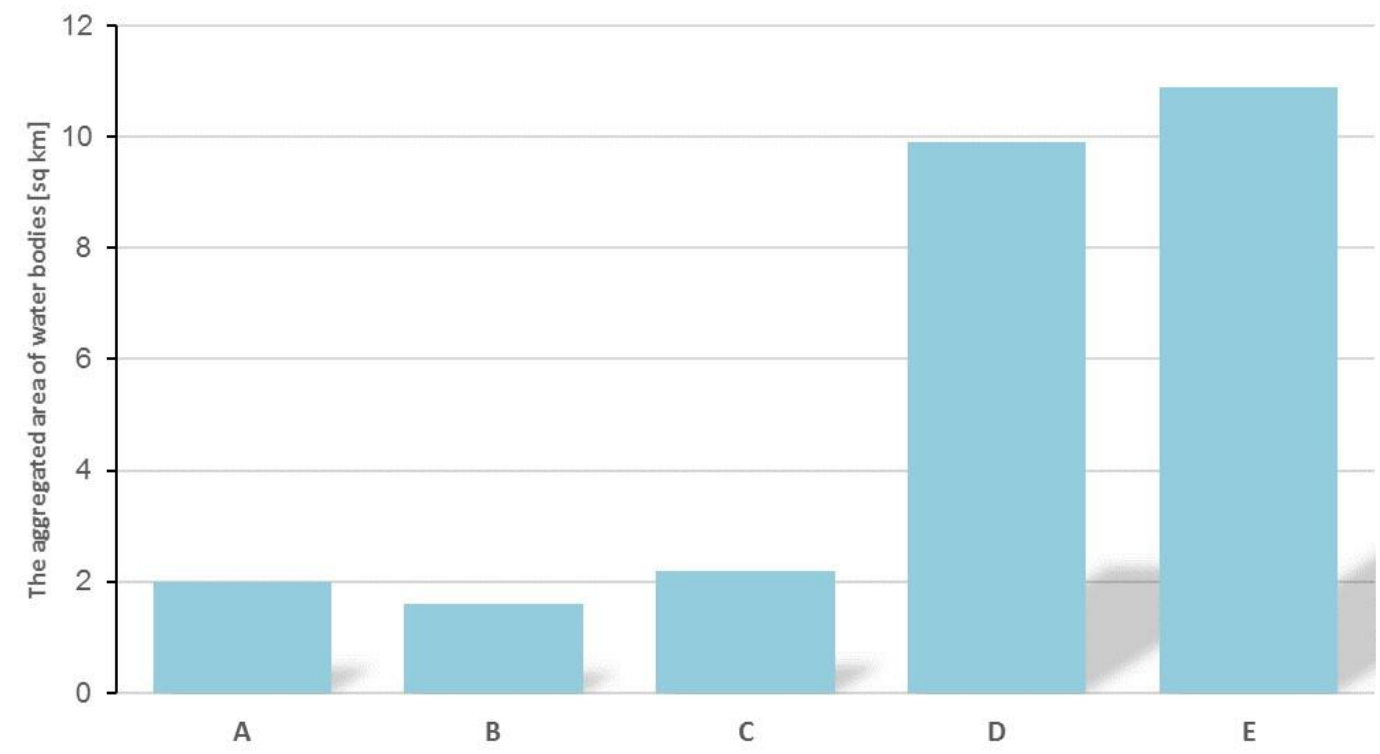

Fig. 7. The aggregated area of water bodies provided for specific time periods: A - the beginning of the 19th century, B - the end of the $19^{\text {th }}$ century, $\mathrm{C}$ - the beginning of the $20^{\text {th }}$ century, D the end of the $20^{\text {th }}$ century, $\mathrm{E} \neg$ the beginning of the $21^{\text {st }}$ century (own study based on databases) 


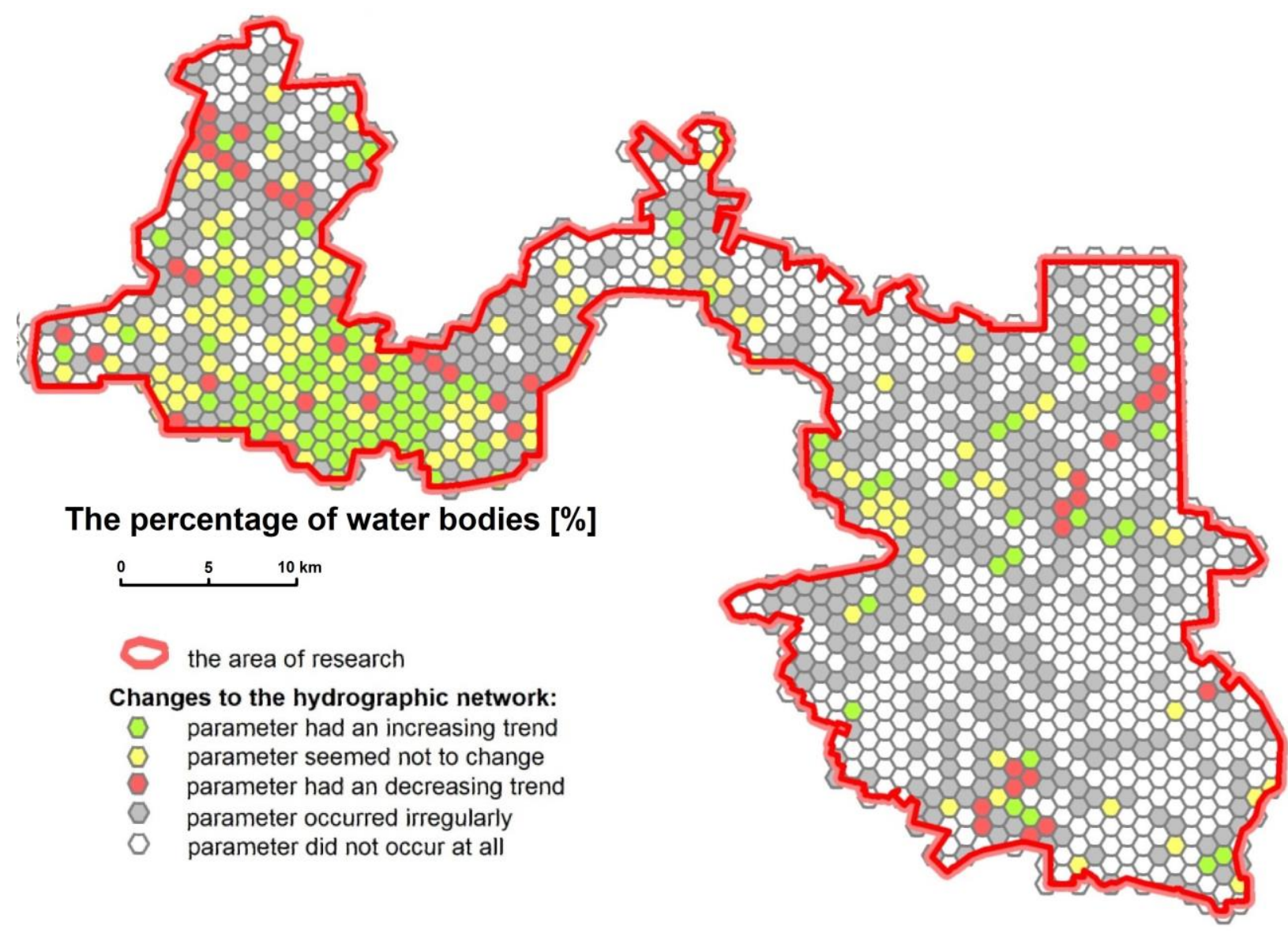

Fig. 8. Map of changes to the percentage of water bodies (own study based on the created databases)

\section{Outcomes analysis}

In the beginning of the $19^{\text {th }}$ century watercourses were mostly of a natural character. The majority of these ran through unconverted, meandering river beds except the parts where artificial lakes had been established. During this period watercourses were strongly supplied with the water which came from the mines. A lot of suspension in these waters led the river beds to be gradually sealed and to the loss of the hydraulic connection between them and the substrate (CZAJA, 1999). By the end of the 19th century the surface hydrographic network was affected mainly by river training actions which, in turn, was performed in order to, prevent the ore mine workings from flooding. It was also found that parts of, or even whole watercourses, have gone because of water infiltrating into the substrate (CZAJA, 2005). These processes resulted in the shortening of larger rivers by even a few kilometers (e.g. Kozi Bród by $6.2 \mathrm{~km}$, Biała by $6.3 \mathrm{~km}$ ) and in the complete disappearance of many smaller ones, e.g. Kaczawa in the Bytomka catchment. Described modifications was the direct reason why the drainage density has fallen. Furthermore, because of the fact that the localized ore exploitation areas was associated with the urbanization taking place in their vicinity (Olkusz, Bytom, Tarnowskie Góry), this stands as another factor which impacted the above mentioned process of change. The digging activities related to the erection of a new building was of high importance as well, because they breached the original surface structure. Within the area intended for buildings a number of river training actions were performed (CZAJA, 1999, 2005). Watercourse networks in the areas not affected by drainage have undergone only slight changes, or the drainage density has grown up as a result of establishing new ditches or rivers responsible for carrying mining water. The Orzeł Biały ditch can serve as an example of such a watercourse, since it transports the water from the mine to the Brynica river. The ditch was built at the end of the 19th century. Another example is the Baba river whose source had already vanished by the beginning of the $19^{\text {th }}$ century, however, its river bed was, after previous sealing, used to carry off mining water (CZAJA, 1999, Fig. 6).

The turn of the $19^{\text {th }}$ and $20^{\text {th }}$ centuries did not result in any major changes to the hydrographic network. When the drainage of some ore mine workings was discontinued the underground 
water table increased and caused partial or full restoration of some watercourses. In the most explicit way, this was observed in the Tarnowskie Góry area where the right bank River Drama supplies have been gradually restored. Since the drainage ditches have been built, the drainage density has also increased within the areas mostly covered by forests. Those of other character, where ore exploitation, as well as the coal mining, have taken place, because of water infiltration into the substrate, river training actions, and ongoing urbanization, these have caused a decrease in the drainage density. Length changes of the region's main watercourses were insignificant and were caused predominantly by sealing the river bed and river training in order to prevent the ore mine workings from flooding (KROPKA, 2003, CZAJA, 2005). The disappearance of some minor watercourses have been observed. For example, at the beginning of the 20th century, the River Bytomka had only two tributaries, whereas at the beginning of the $19^{\text {th }}$ century there were 14 (Table 1). This translated directly into a drainage density reduction. These changes were mostly seen in the areas which were under the influence of coal mining and urbanization which somewhat intensified the impact caused by the ore mining. The overlap of ore and coal excavation was the reason why far more river training actions were undertaken on the surface hydrographic network in order to reduce the risk of water infiltration to the workings of the mine (CZAJA, 2005, Fig. 2).

Due to the discontinuation of further ore exploitation and to the suspension, or centralization, of the mine drainage, at the turn of the $20^{\text {th }}$ and $21^{\text {st }}$ centuries, some specific modifications in the hydrographic network were observed. In the urban areas, the watercourses did not change when compared to their state at the beginning of the $20^{\text {th }}$ century. Length changes did not exceed a few hundred meters and were caused by river training or river bed modifications made in order to allow a river to provide not only its own water but also sewage waters. The River Bytomka can serve as an example. Its upper part was adapted so it could transport the mining waters from the Centrum coal mine. On the other hand, the areas where no urbanization took place, and where the underground water table grew gradually after the ore mine workings had no longer been drained, a drainage density increase was observed. This was directly connected with the fact that the water table aligned with the level ordinates of the dry river valleys. Such an effect was especially observed in the areas where hard coal was extracted since the subsidence of the ground reached even dozens of meters in places. Thus the river valley profiles have undergone some modifications which have caused the lowering of the base of erosion as well as the underground water effluent to the surface (KRóL-KORCZAK, 2005). That is why the changes of the hydrographic network parameters observed in the converted areas were particularly clear in the Bytom part of the research area. In turn, the areas not affected by anthropogenic stress (green areas, forests, farmlands) have also been those characterized by the growth of the drainage density as well as by the aggregated length increase of the tributaries, which was connected with the development of drainage ditches (Fig. 2).

The main element of the hydrographic network, which has changed in the most dynamic way, was the water bodies. At the beginning of the $19^{\text {th }}$ century, there were not many of them and the existing ones were mostly of artificial character. The intention was to use the water to run water structures (sawmills, fullers, forges). Thus most of the water bodies were open (70\%), whilst the rest were reservoirs created within the open pit mines (after excavation of iron, lead or rock resources had been discontinued). The described characteristic structure translated into a number of water bodies within a specific size range. The vast majority represented the smallest of them, whose area ranged between 0.1 and 1.0 ha and which occurred in the pits being formerly an open pit mine. In turn, the group of small and medium water bodies, whose area was between 1.0 and 5.0 ha, consisted of artificial lakes (HADAŚ, 2000 , Fig. 4-7). At the turn of $19^{\text {th }}$ and $20^{\text {th }}$ centuries, a four-fold rise in the number of water bodies was observed and this was due to the increasing impact of different types of anthropogenic stress (urbanization, the impact caused by ore and coal mining). As a result, many industrial water bodies were established in the near vicinity of factories and other facilities of industrial character as well as an increase in the number of artificial lakes created in the pits. Moreover, some overflow lands appeared in the depressions caused by coal mining. The whole process did not result, however, in an increase in the area of aggregated water bodies which, during the 19th century, have even shrunk by $0.3 \mathrm{~km}^{2}$ because of the liquidation, or disappearance, of large artificial lakes, which existed in the early 1900s. At the turn of the 19th and $20^{\text {th }}$ centuries, the small water bodies whose area was between 0.1 and 0.5 ha, dominated the region. And, despite the fact that the number of them in the beginning of the $20^{\text {th }}$ century was 
lower than at the end of the 19th century, their aggregated area increased by almost $0.4 \mathrm{~km}^{2}$. The process could be explained predominantly by the progressive ground subsidence which, in effect, caused some minor overflow lands to combine with each other into bigger ones. Furthermore, it also influenced the size of groups of small and medium water bodies (1.0 to $5.0 \mathrm{ha}$ ), which doubled by the end of the 19th century (JANKOWSKI, 1991, RZĘTAŁA, 2008, Fig. 4-8).

What is significant in terms of the number and area changes of water bodies, are three processes during this period: the ongoing ground subsidence as a result of coal mining, mainly in the Bytom area, reduction of the drain established for ore mining, the reclamation of water bodies in order to allow water-related activities as well as building artificial lakes to serve as flood protection and for recreational purposes. The first factor translated into the creation of subsidence troughs or caves, so were the places where water from precipitation could easily be stopped and stored - the direct reason why some minor water bodies formed, or mixed, with others creating bigger ones (RzĘTAEA, 2008). The second process has been a direct factor causing the rise of the first level underground water table in areas previously drained, which resulted in underground water infiltration into existing land depressions. Finally, the third process led to the creation of large water bodies (over 10 ha of the area; these are, inter alia: Kuźnica Warężyńska, Nakło-Chechło, Sosina, PrzeczyceSiewierz Reservoir) which were used mainly for recreational purposes. In consequence, the aggregated area of water bodies (ca. $10 \mathrm{~km}^{2}$ ) has risen almost five-fold when compared to the situation up to the first half of the $20^{\text {th }}$ century (ca. $2 \mathrm{~km}^{2}$ ) (RZĘTAŁA, 2008, Fig. 4-8).

The presence of wetlands was closely linked to the processes affecting the rest of the hydrographic network structure of elements. Definitely, a high percentage of the wetland areas in the beginning of the $19^{\text {th }}$ century were related to the natural character of the valleys. River training and establishing a network of drainage ditches translated into the disappearance of such areas in the near vicinity of watercourses. Progressive ground subsidence due to coal mining activities and to terrain drainage, that had been caused by lead and zinc ore mining, led to local infiltration of underground waters into land depressions and so the wetlands were formed. Over the years these, have transformed into overflow lands (KRóL-KORCZAK, 2005). A characteristic trend of changes to this parameter has been observed only locally, in the forest areas. Places, where the drainage density increased, were also those where the percentage of wetlands decreased (Fig. 3).

\section{Conclusions}

The structure of the surface hydrographic network in the Silesia-Cracow deposit area underwent many transformations during the studied period. These include some specific ones, as follows:

1) An increase in the drainage density in forest areas;

2) A decrease in the drainage density in urbanized areas;

3) An increase in the percentage of water bodies in areas affected by coal mining in the long term;

4) A decrease in the total area covered by wetlands;

5) Lack of regularity in terms of the area of wetland coverage.

However, none of the above occurred only within the areas affected by the lead and zinc ore mining. On the contrary, they were caused to a large extent by other agents of anthropogenic stress or by factors co-existing with each other where ore mining is only one of many. It can be concluded that processes such as urbanization, coal mining or excavation performed in sandpits were of a much higher impact on the structure of the hydrographic network during the studied period. Within this time, the net was already characterized by heavy transformations it had undergone before and anthropogenic stress factors were so differentiated that it is difficult to assess which of the observed changes was caused only and directly by lead and zinc ore mines. In the clear majority of cases, the influence generated by such exploitation was superimposed with other factors. Modifications of the surface hydrographic network structure related to ore mining during the period from the beginning of the $19^{\text {th }}$ century to the beginning of the $21^{\text {st }}$ century were mainly of an indirect character. Moreover, they often were conditional on local environmental and economic agents. These are, inter alia, as follows:

1) Length shortening in the case of the main watercourses existing within the drained area, caused by the disappearance of the sources, or by river training and river bed sealing so the water cannot infiltrate through the substrate. These two latter questions were highly intensified due to the ongoing urbanization and to the terrain drainage caused by mining other than for lead and zinc ore.

2) The disappearance of minor watercourses because of water infiltrating the drained substrate 
which is a process highly affected by urbanization and other mining types.

3) Creation of small, short-term water bodies in mining pits.

4) The disappearance of wetlands caused by river training and water soaking into the drained substrate, which is also related to urbanization.

5) Restoration of some minor watercourses within dry valleys in forest areas where the underground water table has been gradually recovering. Seen especially within the coal mining areas where the land has undergone many terrain modifications .

6) Creation of wetlands within land depressions and caused by an increase in underground water table level after the drainage had been reduced. Seen especially within subsidence troughs.

7) Creation of wetlands within unconverted river valleys in which the water flow ratio increased significantly because of water being transported out of the zinc and lead ore mines.

\section{References}

Bujwid H. 1966. Graficzna metoda wyznaczania maksymalnej wydajności studni, powierzchni filtra, dopuszczalnej prędkości wlotowej na filtrze i zasięgu leja depresyjnego. Przegl. Geol., 14, 1: 18-19.

Czaja S. 1999. Zmiany stosunków wodnych $w$ warunkach silnej antropopresji na przykładzie konurbacji katowickiej. Prace Nauk. Uniw. Śląskiego w Katowicach, nr 1782, Katowice.

Czaja S. 2005. Changes in river discharge structure and regime in mining-industrial-urban areas. Regional Environ. Change J., 5: 18-26.

Hadaś T. 2000. Przyroda i jej przemiany w dziejach Tarnowskich Gór. [in:] Drabina J. (ed.) Historia Tarnowskich Gór. Muzeum w Tarnowskich Górach: 693-774.
Jankowski A.T. 1991. Wystepowanie antropogenicznych zbiorników wodnych na terenie Bytomia w okresie 18111989. Kształt. środ. geogr. ochr. przyr. obsz. uprzem. zurban., 3: 21-30.

Kondracki J. 2000. Geografia regionalna Polski. PWN, Warszawa. Kropka J. 2003. Rejon bytomski. [in:]. Wilk Z., Bocheńska T. (eds) Hydrogeologia złóż i problemy wodne górnictwa. Uczel. Wyd. Nauk.-Ddyd. AGH, Kraków: 211-242.

Król-Korczak J. 2005. Wpływ eksploatacji kruszyw naturalnych na środowiska przyrodnicze. Górnictwo i geoinżynieria, 29, 4: 73-82.

Różkowski A., Wilk Z. 1980. Warunki hydrogeologiczne złóż rud cynku i ołowiu regionu śląsko - krakowskiego. Prace Inst. Geol., Wyd. Geol., Warszawa.

Rzętała M. 2008. Funkcjonowanie zbiorników wodnych oraz przebieg procesów limnicznych $w$ warunkach zróżnicowanej antropopresji na przykładzie regionu górnośląskiego. Wyd. Uniw. Śląskiego, Katowice.

dm.pgi.gov.pl [02.2016]

\section{Carthografic sources}

Hauptm. v. Kopystyński (ed.), 1861-62. West Galizien, scale about 1:28 000 .

Lempicki M., Hattowski A., 1891. Flötzkarte des Polnischen Steinkohlenbeckens.

Mapa Topograficzna Polski, 1994, 1:10 000, Główny Geodeta Kraju, Warszawa.

Mapa topograficzna WIG, 1939-1944, 1:25 000, Wojskowy Instytut Geograficzny, Warszawa.

Mapy.geoportal.gov.pl (Baza danych TBD) [01.2017 - 04.2017].

Materials from Archives ZGH Bolesław.

Materials from Tarnowskie Góry Historic Mine.

Mayer v. Heldensfeld A., 1802. Esquelette - Der Aufnahms Karte von West Gallizien, skala około 1:28 000

Messtischblätter, 1883, 1:25 000, Preußischen Landesaufnahme Reichsamt Für Landesaufnahme.

Preussische Ur- Messtischblätter, 1823, 1: 25 000, Königlich Preußischen Landesaufnahme. 